\title{
IMPLEMENTASI METODE KENDALI FUZZY LOGIC UNTUK KESTABILAN SIKAP QUADCOPTER TERHADAP SUMBU ROLL DAN SUMBU PITCH
}

\author{
A.A. Gde Jenana Putra ${ }^{1}$, Porman Pangaribuan ${ }^{2}$, Agung Surya Wibowo ${ }^{3}$ \\ 1, 2,3 Fakultas Teknik Elektro, Universitas Telkom \\ ${ }^{1}$ jenanaputra@student.telkomuniversity.ac.id, ${ }^{2}$ porman@telkomuniversity.ac.id, \\ 3agungsw@telkomuniversity. ac.id
}

\begin{abstract}
Abstrak
Salah satu jenis pesawat Unmanned Aerial Vehicle (UAV) yang sedang berkembang luas di kalangan masyarakat maupun di bidang militer adalah Quadcopter. Quadcopter dapat digunakan untuk melakukan survei lokasi dari udara, dokumentasi, aerial cinematography dan juga dapat melakukan inspeksi rahasia dalam melacak posisi musuh, terutama di wilayah yang tidak aman untuk dilewati para tentara. Pada saat terbang, quadcopter sering mendapatkan hambatan yang dapat menyebabkan kestabilan terganggu, sehingga menyebabkan pergerakan yang tidak diinginkan. Dengan menggunakan Fuzzy Logic Control tipe Sugeno dan integrator dengan konstanta integrator $(K i=0.01)$ sebagai metode kendali, quadcopter dapat stabil dan dapat mempertahankan posisinya sesuai dengan set point yaitu $\left(0^{\circ}\right)$ pada saat mendapatkan gangguan maupun pada saat terbang. Rise time ketika diberikan gangguan yaitu kurang dari 1.3 detik dan simpangan osilasi respon di sepanjang nilai set point pada saat quadcopter terbang dan diberikan gangguan adalah $+15^{\circ}$ sampai $-15^{\circ}$.
\end{abstract}

Kata Kunci: quadcopter, fuzzy, integrator, kestabilan.

\section{Abstract}

One type of UAV (Unmanned Aerial Vehicle) aircraft that well-developed in community and in military field is quadcopter. Quadcopter can be used for site surveys from air, documentation, and aerial cinematography. In addition, quadcopter can be used as well to conduct secret inspections, particulary to track enemy positions, especially in areas that the soldiers is dangerous if they are on there. When a quadcopter flies, it usually gets a disturbance, which can disturb the stability of quadcopter and causes undesired movements. By using fuzzy logic control Sugeno type and integrator, with integrators constants $(K i=0.01)$ as a control method, quadcopter can be stable and can maintain its stability around set point $\left(0^{\circ}\right)$ when it was flying and getting a disturbance. The deviation of the quadcopter response oscillation along its set point value when getting a disturbance and when flying was in interval $+15^{\circ}$ to $-15^{\circ}$.

Key Words: quadcopter, fuzzy, integrator, stability

\section{Pendahuluan}

Seiring dengan berkembangnya teknologi, pesawat jenis Unmanned Aerial Vehicle (UAV) berkembang luas di kalangan masyarakat dan berkembang luas di bidang militer. Salah satu pesawat jenis UAV tersebut adalah quadcopter. Beberapa kegunaan quadcopter di kalangan masyarakat, yaitu untuk melakukan survei lokasi dari udara, dokumentasi, dan aerial cinematography. Pada bidang militer, quadcopter digunakan untuk melakukan inspeksi rahasia dalam melacak posisi musuh terutama di wilayah yang tidak aman untuk dilewati para tentara.

Ketika quadcopter melayang atau hovering biasanya mendapatkan gangguan atau disturbance sehingga mengakibatkan kestabilan dari quadcopter terganggu dan dapat menyebabkan gerakan yang tidak diinginkan. Gangguan tersebut dapat berupa angin atau beban yang tidak sama pada setiap lengan quadcopter. Oleh karena itu, perlu adanya metode kendali untuk menjaga kestabilan quadcopter agar tetap stabil ketika mendapatkan gangguan. Pada penelitian ini, Fuzzy Logic Control (FLC) dan integrator diimplementasikan ke sistem kestabilan sikap quadcopter pada sumbu roll dan sumbu pitch. Metode kendali fuzzy logic dipilih untuk sistem stabilisasi sikap Quadcopter terhadap sumbu roll dan sumbu pitch, karena fuzzy logic dapat memberikan kontrol yang lebih tepat /sesuai untuk sistem nonlinier pada quadcopter [7], dan fuzzy logic merupakan metode 
kendali yang nonlinier juga sesuai untuk sistem yang nonlinier [8]. Pengumpulan informasi terkait tentang kestabilan quadcopter pada sumbu roll dan sumbu pitch, pengukuran empirik dan analisis statistika, perancangan sistem, dan simulasi digunakan dalam penelitian ini untuk merancang quadcopter yang tetap stabil ketika mendapatkan gangguan. Beberapa penelitian sebelumnya terkait dengan kestabilan quadcopter telah banyak diteliti oleh beberapa orang. Dharmawan dkk. memodelkan sistem kendali PID pada quadcopter dengan Metode Euler Langrange [1]. Sattar dan Ismail memodelkan fuzzy logic control untuk quadcopter [7]. Abbasi dkk. mengontrol quadcopter menggunakan fuzzy untuk tuning Propotional-Integral-Derivative(PID) pada hovering mode [8]. Pada penelitian ini, digunakan metode kendali fuzzy logic dan integrator yang digunakan secara perarel untuk metode kendali quadcopter dan menggunakan lima membership fuction pada setiap inputnya.

\section{Dasar Teori dan Perancangan System}

\subsection{Quadcopter}

Quadcopter merupakan jenis robot terbang atau pesawat tanpa awak yang bergerak terbang dengan menggunakan gaya dorong yang dihasilkan dari perputaran keempat rotornya [1]. Quadcopter dikendalikan dengan menyesuaikan kecepatan sudut yang dihasilkan oleh rotor yang berputar [1]. Untuk mengurangi pergerakan akibat efek inersia pada quadcopter, motor yang berdekatan harus memiliki arah putaran motor yang berbeda, sedangkan motor yang berseberangan harus memiliki arah putar yang sama. Gambar 1 memperlihatkan konfigurasi motor pada suatu quadcopter.

Pergerakan roll dan pitch pada quadcopter terjadi karena kecepatan putar setiap dua buah motor quadcopter berbeda satu sama lain. Berdasarkan Gambar 1 , penyebab terjadinya sikap roll dan pitch pada Quadcopter yaitu :

1. Sikap roll terjadi ketika kecepatan putar motor 1 dan motor 4 lebih besar dari kecepatan putar motor 2 dan motor 3 atau sebaliknya.

2. Sikap pitch terjadi ketika kecepatan putar motor 1 dan motor 2 lebih besar dari kecepatan putar motor 4 dan motor 3 atau sebaliknya.

Dalam penentuan dinamika sistem quadcopter, dua buah referensi frame quadcopter harus ditetapkan. Dua jenis referensi frame pada Quadcopter yaitu:

1. Earth Frame (E-Frame)

2. Body Frame (B-Frame)

E-Frame merupakan nilai acuan yang akan digunakan dimana XE merepresentasikan arah utara bumi, YE merupakan representasi arah barat bumi, dan ZE merupakan arah menuju pusat bumi [1]. Sedangkan B-Frame merupakan nilai acuan pada body dari

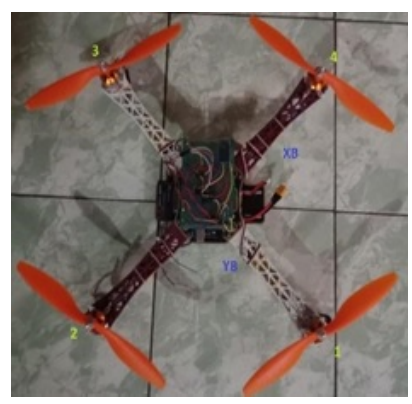

\section{Gambar 1. Konfigurasi Motor Quadcopter}

quadcopter. $\mathrm{XB}$ merupakan sumbu $\mathrm{x}$ dari quadcopter, YB merupakan sumbu y dari quadcopter, dan ZB merupakan sumbu z dari quadcopter.

Persamaan dinamika quadcopter diturunkan dari persamaan Angular Rate quadcopter yaitu:

$$
\begin{gathered}
p=\dot{\emptyset} c \theta-\dot{\varphi} c \emptyset s \theta \\
q=\dot{\theta}+\dot{\varphi} s \emptyset
\end{gathered}
$$

Dari persamaan (1) dan (2), c merupakan fungsi cosinus sedangkan s merupakan fungsi sinus. Persamaan (1) dan (2) merupakan persamaan nonlinier dikarenakan terdapat fungsi cosinus dan sinus. Oleh karena itu, perlu adanya proses linierisasi. Proses linierisasi ini ditinjau ketika Quadcopter berada di titik equilibrium, yaitu semua sudut yang ditinjau nilainya mendekati nol, sehingga didapatkan persamaan (3):

$$
\sin \theta \approx \theta, \sin \emptyset \approx \emptyset, \cos \theta \approx \cos \emptyset \approx 1
$$

Dengan mensubstitusikan persamaan (3) ke persamaan (1) dan (2), didapatkan persamaan (4) dan (5):

$$
\begin{aligned}
& p=\dot{\emptyset}-\dot{\varphi} \theta \\
& q=\dot{\theta}+\dot{\varphi} \emptyset
\end{aligned}
$$

Jika ditinjau pada titik equilibrium, maka didapatkan hasil persamaan (6):

$$
\dot{\varphi} \theta \approx \dot{\varphi} \emptyset \approx 0
$$

Sehingga persamaanya menjadi persamaan (7), (8), dan (9):

$$
\begin{gathered}
p=\dot{\emptyset} \\
q=\dot{\theta} \\
\text { I. }\left[\begin{array}{l}
\dot{p} \\
\dot{q}_{r}
\end{array}\right]=\left[\begin{array}{c}
U_{2 x} \\
U_{2 y} \\
U_{2 z}
\end{array}\right]-\left[\begin{array}{l}
p \\
q \\
r
\end{array}\right] x I .\left[\begin{array}{l}
p \\
q \\
r
\end{array}\right]
\end{gathered}
$$

Dimana I merupakan matriks Inertia yang didefinisikan persamaan (10):

$$
I=\left[\begin{array}{ccc}
I_{x x} & 0 & 0 \\
0 & I_{y y} & 0 \\
0 & 0 & I_{z z}
\end{array}\right]
$$


Jika persamaan (9) dan persamaan (10) disubstitusikan akan didapat persamaan sebagai (11) dan (12):

$$
\begin{aligned}
& I_{x x} \cdot \dot{p}=U_{2 x}-I_{y y} \cdot q \cdot r+I_{z z} \cdot q \cdot r \\
& I_{x x} \cdot \dot{q}=U_{2 y}+I_{x x} \cdot p \cdot r-I_{z z} \cdot p \cdot r
\end{aligned}
$$

Karena $p \approx \dot{\emptyset}, q \approx \dot{\theta}$, dan $q r \approx p r \approx p q \approx \dot{\emptyset} \dot{\varphi} \approx 0$

Maka didapatkan persamaan akhir seperti persamaan (13) dan (14):

$$
\begin{aligned}
& \ddot{\emptyset}=\frac{U_{2 x}}{I_{x x}} \\
& \ddot{\theta}=\frac{U_{2 y}}{I_{y y}}
\end{aligned}
$$

Nilai variabel yang terdapat pada penurunan persamaan dapat ditentukan nilainya dengan menggunakan persamaan (15) dan (16) berikut:

$$
\begin{aligned}
& U_{2 x}=l b\left(\left(\omega_{2}^{2}+\omega_{1}^{2}\right)-\left(\omega_{3}^{2}+\omega_{4}^{2}\right)\right) \\
& U_{2 y}=l b\left(\left(\omega_{2}^{2}+\omega_{3}^{2}\right)-\left(\omega_{1}^{2}+\omega_{4}^{2}\right)\right)
\end{aligned}
$$

Persamaan (14) dan (15) kemudian ditransformasi Laplace sehingga menjadi:

$$
\begin{gathered}
\frac{\emptyset(s)}{U_{2 x}(s)}=\frac{l b}{I_{x x} s^{2}} \\
\frac{\theta(s)}{U_{2 y}(s)}=\frac{l b}{I_{y y} s^{2}}
\end{gathered}
$$

dengan,

$b=$ Thrust motor $(\mathrm{kg})$

$l=$ Panjang lengan Quadcopter $(\mathrm{m})$

$\omega=$ Kecepatan rotasi motor brushless DC (rpm)

$I_{x x}=$ Momen inersia pada sumbu $\mathrm{x}\left(\mathrm{kg} \cdot \mathrm{m}^{2}\right)$

$I_{y y}=$ Momen inersia pada sumbu y $\left(\mathrm{kg} . \mathrm{m}^{2}\right)$

$\ddot{\emptyset}=$ Percepatan sudut pada sumbu roll $\left(\mathrm{rad} / \mathrm{s}^{2}\right)$

$\ddot{\theta}=$ Percepatan sudut pada sumbu pitch $\left(\mathrm{rad} / \mathrm{s}^{2}\right)$

\subsection{Sistem Inferensi Fuzzy}

Dari persamaan dinamika quadcopter di atas, disebutkan bahwa persamaan dinamika quadcopter merupakan persamaan non linier karena terdapat fungsi cosinus dan sinus. Oleh karena itu, fuzzy logic control diimplementasikan ke sistem quadcopter. Salah satu proses dalam penggunaan fuzzy logic control adalah Sistem Inferensi fuzzy, yaitu penarikan kesimpulan dari beberapa kaidah fuzzy. Input dalam Fuzzy Inferensi Sistem (FIS) merupakan crisp value dan Output dari FIS juga merupakan crisp value. Proses-proses pada FIS yaitu sebagai berikut:

1. Fuzzyfication

Fuzzyfication adalah proses memetakan nilai crisp ke dalam himpunan fuzzy dan menentukan derajat keanggotaan di dalam himpunan fuzzy.
2. Fuzzy Inference Engine

Pada Fuzzy Inference Engine terdapat Fuzzy Rule Base yang fungsinya untuk mendapatkan nilai dari variable linguistic dari aturan-aturan (rules) yang ditetapkan.

\section{Defuzzyfication}

Defuzzyfication merupakan proses merubah suatu nilai himpunan fuzzy kedalam bentuk nilai crisp.

\subsection{Perancangan Sistem}

Pada bagian ini, digunakan gabungan dua buah metode kendali untuk sistem stabilisasi quadcopter pada sumbu roll dan sumbu pitch yaitu dengan menggunakan metode fuzzy logic control tipe Sugeno dan PID yang diimplementasikan pada bagian kontroler. Tetapi pada bagian PID yang hanya digunakan pada penelitian ini adalah integrator. Sinyal error dan delta error yang menjadi input bagi fuzzy logic control dan integrator, merupakan selisih hasil antara nilai set point kecepatan sudut dengan nilai kecepatan sudut yang terbaca oleh sensor MPU6050.

Gambar 2 merupakan diagram blok untuk sistem stabilisasi sikap Quadcopter terhadap sumbu roll dan sumbu pitch. Sedangkan, Gambar 3 adalah diagram blok sistem untuk blok kontroller. Penjelasan mengenai Gambar 2 dan Gambar 3 yaitu sebagai berikut:

1. Sinyal a merupakan nilai sinyal yang diinginkan (set point) yang berasal dari transmitter.

2. Sinyal b merupakan sinyal (error) antara nilai yang diinginkan dari transmitter dengan nilai angle correctionr.

3. Sinyal c merupakan sinyal kecepatan sudut quadcopter.

4. Sinyal d merupakan sinyal (error) untuk kecepatan sudut quadcopter.

5. Sinyal e merupakan total sinyal PWM yang dihasilkan oleh kontroller.

6. Sinyal f merupakan gaya yang dihasilkan oleh perputaran aktuator dan propeller.

7. Sinyal g merupakan nilai kecepatan sudut quadcopter.

8. Sinyal h merupakan nilai sudut quadcopter.

9. Sinyal $\mathrm{i}$ dan $\mathrm{j}$ masing masing merupakan hasil pembacaan kecepatan sudut dan besar sudut quadcopter.

10. Sinyal $\mathrm{k}$ merupakan angle correctionr terhadap sinyal a.

\subsection{Perancangan Fuzzy Logic Control (FLC)}

Perancangan FLC pada penelitian ini dibagi menjadi perancangan fuzzyfikasi untuk sinyal (error), perancangan fuzzyfikasi untuk sinyal (delta error), perancangan FLC rules yang diimplementasikan pada sistem, dan perancangan output membership function untuk proses defuzzyfikasi. Lima variabel lingusitik 


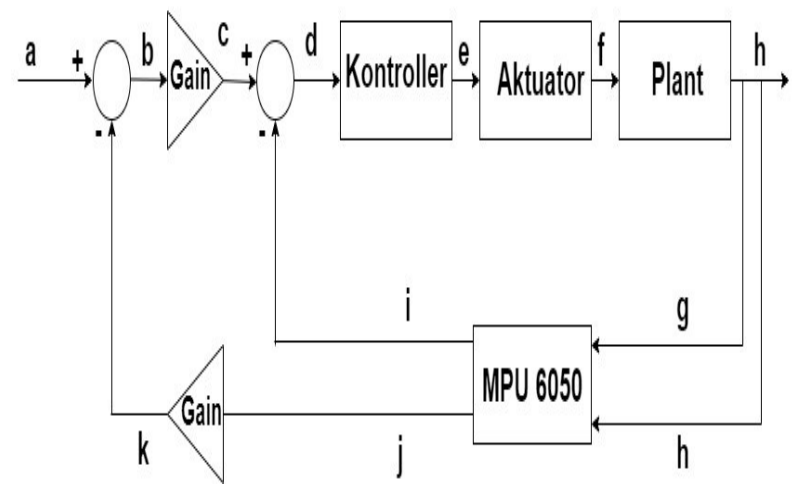

Gambar 2. Diagram Blok Sistem Kestabilan Quadcopter

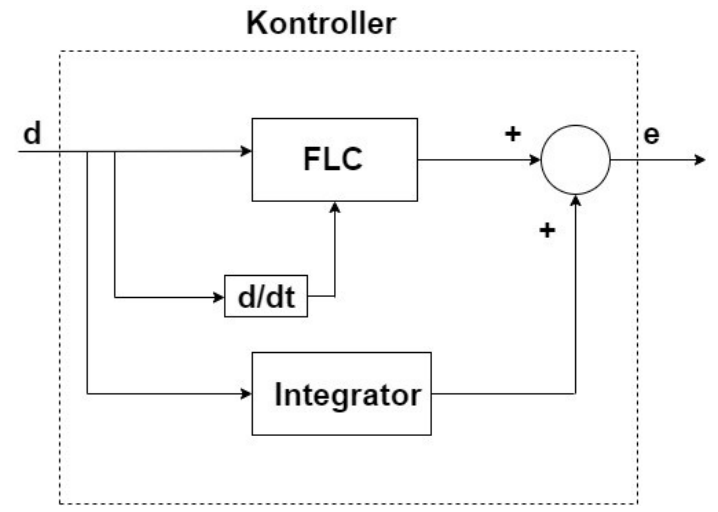

Gambar 3. Diagram Blok Kontroller Quadcopter

digunakan untuk fuzzyfikasi sinyal (error) dan (delta error) untuk masing-masing sumbu roll dan sumbu pitch. Variabel variabel linguistik yang digunakan yaitu NB yang merupakan akronim dari Negative Big, N merupakan akronim dari Negative, $\mathrm{Z}$ merupakan akronim dari Zero, $\mathrm{P}$ merupakan akronim dari Positive dan PB merupakan akronim dari Positive Big.

Gambar 4 menunjukkan membership function untuk sinyal error yang digunakan. Terdapat lima variabel linguistik dan lima membership function yang terdiri dari dua membership function bentuk trapesium dan tiga membership function berbentuk segitiga.

Gambar 5 menunjukkan membership function untuk sinyal delta error yang digunakan pada penelitian ini. Terdapat lima variabel linguistik dan lima membership function yang terdiri dari dua membership function bentuk trapesium dan tiga membership function berbentuk segitiga.

Pada penelitian ini lima variabel linguistik untuk masing-masing fuzzyfikasi sinyal error dan fuzzyfikasi sinyal delta error, sehingga jumlah kombinasi fuzzy rules untuk sistem ini yaitu 25 rules seperti yang ditampilkan pada Tabel 1.

Gambar 6 menunjukkan nilai output membership function. Nilai tersebut akan digunakan pada proses

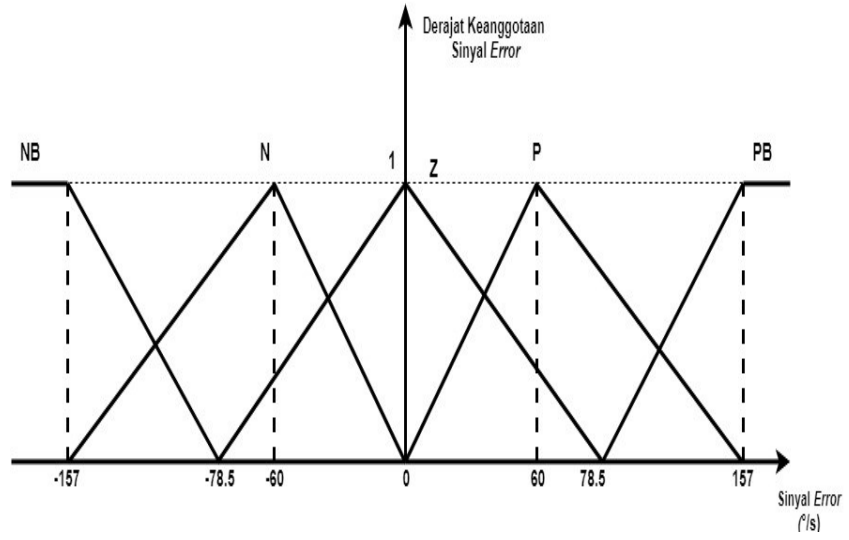

Gambar 4. Fuzzyfikasi Sinyal Errorr

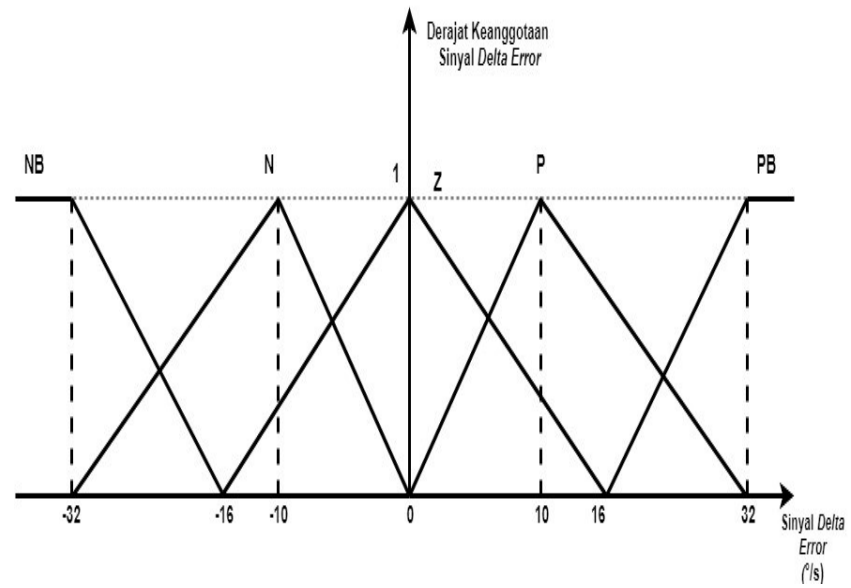

Gambar 5. Fuzzyfikasir Sinyal Delta Errorr

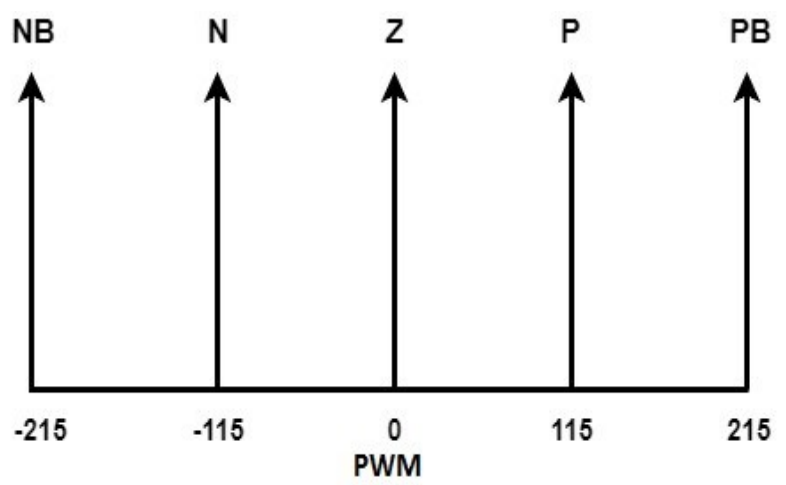

Gambar 6. Output Membership Function 
defuzzyfikasi. Output defuzzyfikasi merupakan sinyal Pulse Width Modulation (PWM) untuk setiap motor. Pada penelitian ini metode defuzzyfikasi yang digunakan yaitu metode pusat luas (CoA). Nilai defuzzyfikasi dapat ditentukan dengan menggunakan formula dibawah ini:

$$
z^{*}=\frac{\sum_{j=1}^{n} z_{j} \mu_{c}\left(z_{j}\right)}{\sum_{j=1}^{n} \mu_{c}\left(z_{j}\right)}
$$

$z^{*}=$ Output defuzzyfikasi

$z_{j}=$ Output fuzzy rules ke $-j$

$\mu_{c}\left(z_{j}\right)=$ Membership value $\mathrm{ke}-j$

\subsection{Perancangan Integrator}

Perancangan sistem kestabilan quadcopter terhadap sumbu roll dan pitch pada penelitian ini menggunakan FLC dan Integrator sebagai metode kendali sikap quadcopter. Integrator ditambahkan sebagai metode kendali pada penelitian ini, dengan tujuan mengurangi steady state error respon Quadcopter terhadap sumbu roll dan sumbu pitch. Konstanta integrator (Ki) yang ditetapkan pada penelitian ini yaitu sebesar $\mathrm{Ki}=0.01$ berdasarkan hasil tuning.

\subsection{Flowchart System Kestabilan Quadcopter}

Gambar 7 menampilkan flowchart system kestabilan sikap quadcopter terhadap sumbu roll dan sumbu pitch menggunakan metode kendali fuzzy logic ditambah integrator. Flowchart pada Gambar 7, menjadi urutan proses dari desain perangkat lunak dengan menggunakan bahasa $\mathrm{C}$ arduino untuk sistem kestabilan sikap quadcopter terhadap sumbu roll dan sumbu pitch.

\section{Hasil Pengujian Respon Quadcopter}

Pengujian yang dilakukan meliputi pengujian respon quadcopter terhadap sumbu roll pada selang waktu tertentu ketika quadcopter diberikan gangguan, pengujian dan analisis respon quadcopter terhadap sumbu pitch pada selang waktu tertentu pada saat quadcopter diberikan gangguan, pengujian rise time quadcopter pada sumbu roll dan pitch, dan pengujian respon kestabilan quadcopter terhadap sudut roll dan pitch pada saat quadcopter sedang terbang. Berikut merupakan beberapa hasil pengujian yang diperoleh dalam penelitian ini.

Gambar 8 dan Gambar 9 menampilkan dua hasil pengujian respon roll quadcopter ketika quadcopter tidak terbang. Pengujian dilakukan selama 30 sampai 40 detik. Gambar 8 merupakan respon quadcopter pada saat diberikan gangguan sinyal impulse sedangkan Gambar 9 merupakan respon quadcopter ketika diberikan beban seberat 1 ons. Berdasarkan pada Gambar 8 dan Gambar 9, desain system control menggunakan FLC dan Integrator yang diimplementasikan ke quadcopter dapat mempertahan
Tabel 1. Fuzzy Rules Sistem Kestabilan Quadcopter

\begin{tabular}{|c|c|c|c|c|l|l|}
\hline \multirow{4}{*}{ Error } & \multicolumn{6}{|c|}{ Delta Error } \\
\cline { 2 - 7 } & & NB & N & Z & P & PB \\
\cline { 2 - 7 } & NB & NB & NB & PB & PB & PB \\
\cline { 2 - 7 } & P & NB & N & P & P & PB \\
\cline { 2 - 7 } & Z & NB & N & Z & P & PB \\
\cline { 2 - 7 } & N & NB & N & N & P & PB \\
\cline { 2 - 7 } & NB & NB & NB & NB & P & PB \\
\hline
\end{tabular}
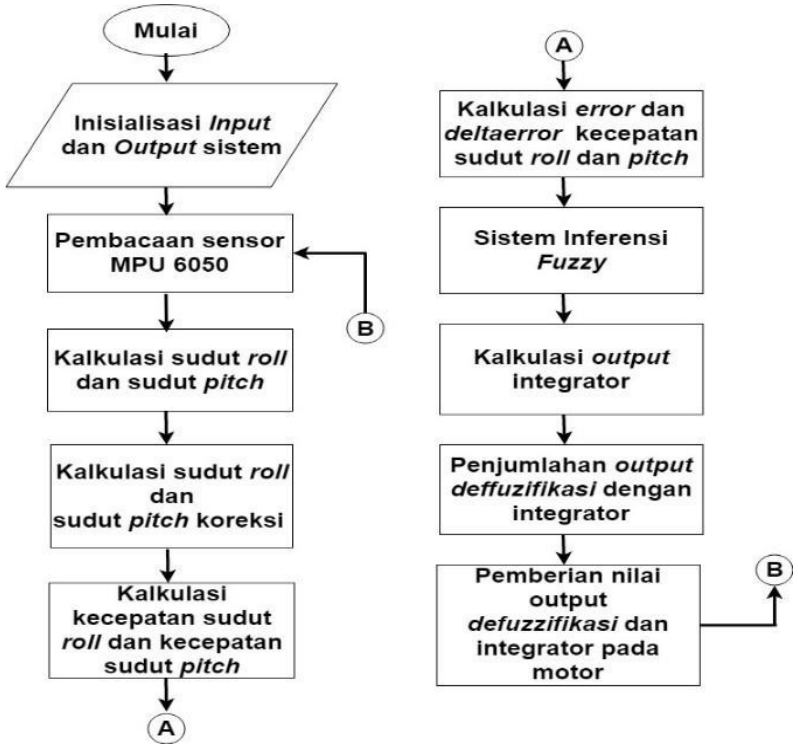

\section{Gambar 7. Flowchart Sistem Kestabilan Quadcopter pada Sumbu Roll dan Pitch}

responya untuk berada pada nilai set point (0), walaupun diberikan disturbance.

Gambar 10 dan Gambar 11 menampilkan dua hasil pengujian respon pitch quadcopter ketika quadcopter tidak terbang. Pengujian dilakukan selama 30 sampai 40 detik. Gambar 10 merupakan respon quadcopter pada saat diberikan gangguan sinyal impulse dan Gambar 11 merupakan respon quadcopter ketika diberikan beban seberat 1 ons. Hasilnya sama seperti sebelumnya bahwa FLC dan Integrator dapat mempertahan respon Quadcopter berada di nilai set point (0) walaupun diberikan disturbance.

Gambar 12 dan Gambar 13 menunjukkan respon Quadcopter pada sumbu roll ketika terbang selama 1 menit. Gambar 12 menunjukkan respon quadcopter tanpa adanya beban tambahan, sedangkan Gambar 13 menunjukkan respon quadcopter pada saat diberikan beban seberat 1 ons. Berdasarkan Gambar 12 dan Gambar 13, FLC dan Integrator yang didesain sebagai metode kendali dapat mempertahankan sikap quadcopter untuk berada di sekitar nilai set point, yaitu (0) walaupun masih terdapat sedikit osilasi dalam rentang waktu yang sangat singkat. 


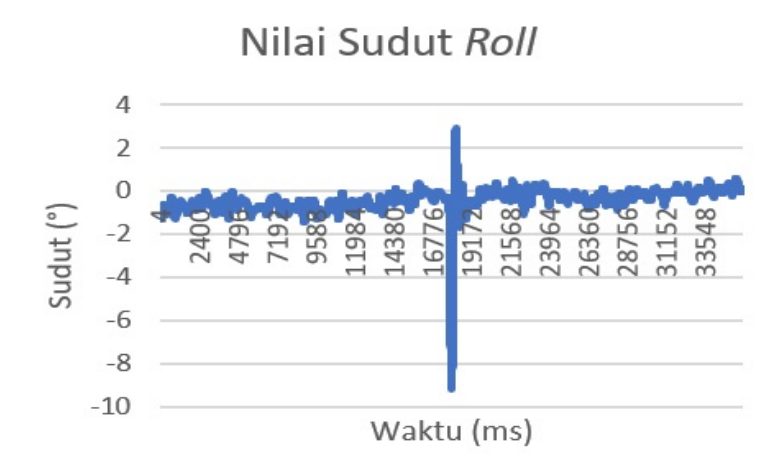

Gambar 8. Hasil Pengujian Respon Sudut Roll Ketika Mendapatkan Gangguan Sinyal Impulse

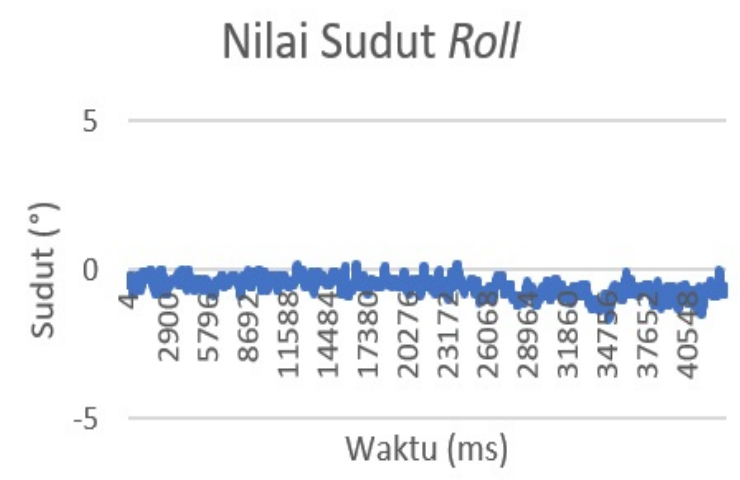

Gambar 9. Hasil Pengujian Respon Sudut Roll Ketika Mendapatkan Gangguan Beban 1 Ons

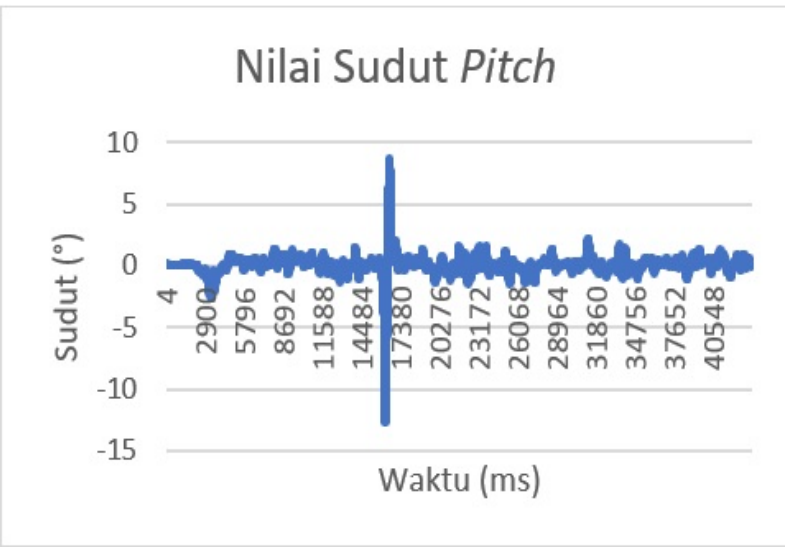

Gambar 10. Hasil Pengujian Respon Sudut Pitch Ketika Mendapatkan Gangguan Sinyal Impulse

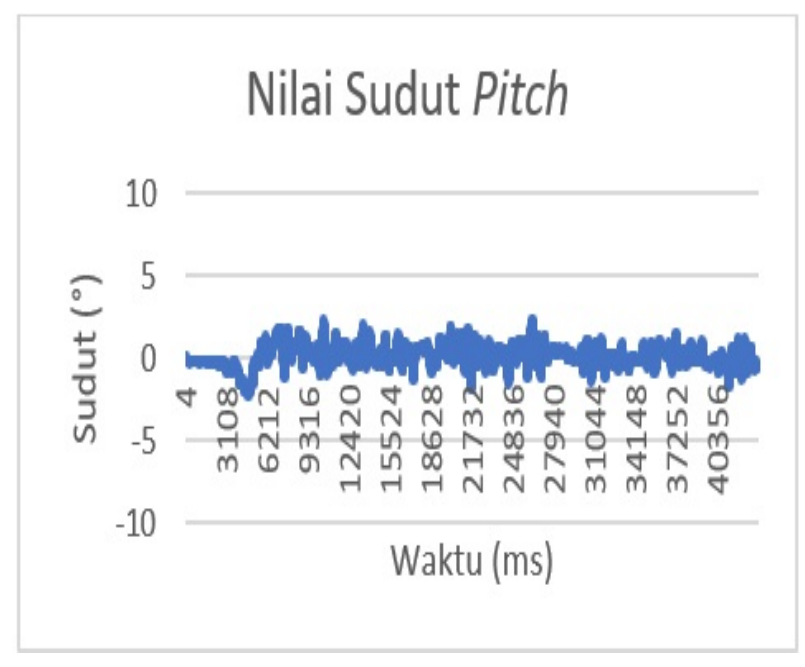
Gambar 11. Hasil Pengujian Respon Sudut Pitch
Ketika Mendapatkan Gangguan Beban 1 Ons

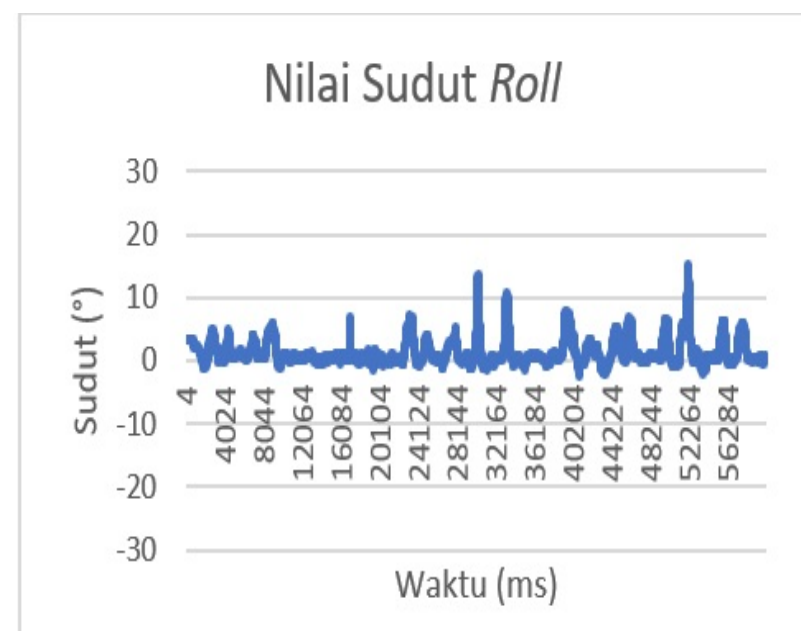

\section{Gambar 12. Hasil Respon Quadcopter Pada Sumbu Roll Tanpa Diberiakan Beban Tambahan}

Gambar 14 dan Gambar 15 menunjukkan respon Quadcopter pada sumbu pitch ketika terbang selama 1 menit. Gambar 14 menunjukkan respon quadcopter tanpa adanya beban sedangkan Gambar 15 menunjukkan respon quadcopter pada saat diberikan beban seberat 1 ons. Seperti hasil pengujian sebelumnya, kombinasi dari FLC dan Integrator yang dirancang ternyata dapat mempertahankan sikap quadcopter untuk berada di sekitar nilai set point ketika mendapatkan disturbance. Walaupun masih terdapat sedikit osilasi, tetapi quadcopter dapat mempertahankan sikapnya sesuai dengan set point dalam rentang waktu yang singkat.

Tabel 2 menunjukkan rise time dari respon quadcopter ketika terbang dan mendapatkan gangguan. Nilai rise time dari tiga kali pengujian untuk masing-masing sumbu roll dan sumbu pitch, yaitu tidak 


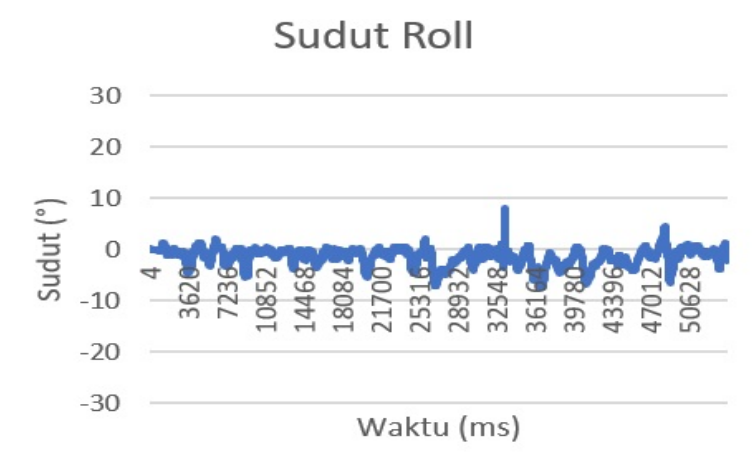

\section{Gambar 13. Hasil Respon Quadcopter Pada Sumbu Roll Dengan Beban Tambahan 1 Ons}

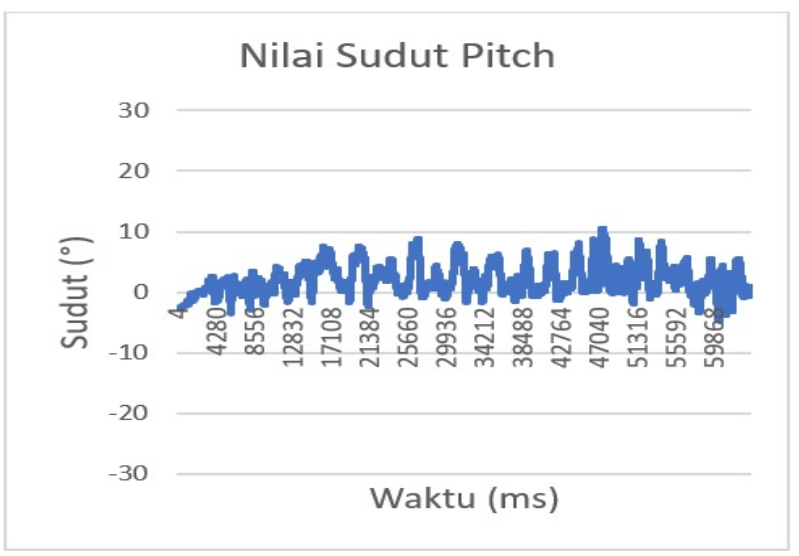

\section{Gambar 14. Hasil Respon Quadcopter Pada Sumbu Pitch Tanpa Diberiakan Beban Tambahan}

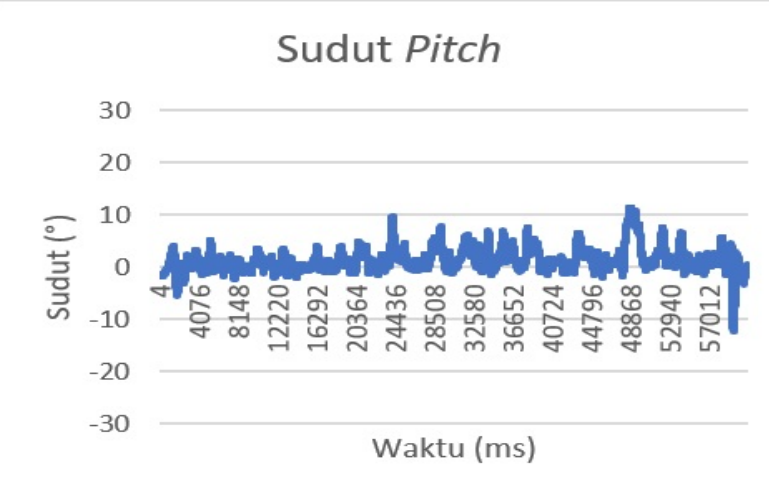

Gambar 15. Hasil Respon Quadcopter Pada Sumbu Pitch Dengan Beban Tambahan 1 Ons
Tabel 2. Hasil Pengujian Rise Time Quadcopterr Pada Sumbu Roll Dan Pitch

\begin{tabular}{|c|c|c|}
\hline No & $\begin{array}{c}\text { Pengujian pada } \\
\text { Sumbu Roll Quadcopter }\end{array}$ & $\begin{array}{c}\text { Waktu } \\
(\mathrm{ms})\end{array}$ \\
\hline 1 & Pengujian ke-1 & 729 \\
\hline 2 & Pengujian ke-2 & 852 \\
\hline 3 & Pengujian ke-3 & 1280 \\
\hline & $\begin{array}{c}\text { Pengujian pada } \\
\text { Sumbu Pitch Quadcopter }\end{array}$ & \\
\hline 1 & Pengujian ke-1 & 492 \\
\hline 2 & Pengujian ke-2 & 360 \\
\hline 3 & Pengujian ke-3 & 832 \\
\hline
\end{tabular}

melebihi waktu 1,3 detik.

\section{Kesimpulan}

Berikut merupakan kesimpulan yang dapat diambil pada penelitian ini yaitu :

1. FLC dan Integrator dapat digunakan bersamaan sebagai metode kendali dalam sistem stabilisasi sikap quadcopter pada sumbu roll dan pitch.

2. Hanya dengan menggunakan lima membership function pada setiap proses fuzzyfikasi sinyal error dan sinyal delta error pada FLC ketika diimplemntasikan bersama dengan integrator, ternyata dapat diterapkan pada sistem stabilisasi sikap quadcopter terhadap sumbu roll dan sumbu pitch.

3. Rise time respon quadcopter ketika mendapatkan gangguan yaitu lebih kecil dari 1,3 detik.

4. Simpangan osilasi respon quadcopter di sepanjang nilai set point ketika quadcopter mendapatkan gangguan dan ketika Quadcopter diikat pada salah satu sumbunya yaitu di antara $-5^{\circ}$ sampai $+5^{\circ}$.

5. Simpangan maksimum dan minimum dari osilasi respon Quadcopter di sepanjang nilai set point ketika mendapatkan gangguan dan ketika terbang yaitu berada diantara $-15^{\circ}$ sampai $+15^{\circ}$.

\section{Pustaka}

[1] A. Dharmawan, Y. Y. Simanungkalit, and N. Y. Megawati, Pemodelan Sistem Kendali PID pada Quadcopter dengan Metode Euler Lagrange, IJEIS - Indones. J. Electron. Instrum. Syst., vol. 4, no. 1, pp. 1324, 2014.

[2] P. Wang, Z. Man, and Z. Cao, Dynamics Modelling and Linear Control of Quadcopter, pp. 498503, 2016.

[3] Vasilis Tzivaras. 2015. Building a Quadcopter with Arduino. Birmingham: Packt Publishing Ltd.

[4] L. P. Ketaren, M. Ma, and M. Rahmawaty, Balancing Robot Beroda Dua Menggunakan 
Metoda Kontrol Proporsional , Integral dan Derivatif, vol. 1, no. 2, pp. 3948, 2015.

[5] Ahmad M. Ibrahim. 2004. Fuzzy Logic for Embedded Systems Applications. Burlington: Newnes.

[6] N. Effendy, A. S. Ashfahani, and A. Yulinggar, Aplikasi Kontrol Logika Fuzzy Pada Sistem Tracking Matahari ( Sun Tracking System ) Panel Photovoltaic, Seminar, vol. 2008, no. Snati, 2008.
[7] M. A. Sattar and A. Ismail, Modeling and Fuzzy Logic Control of a Quadrotor UAV, pp. 14941498, 2017.

[8] E. Abbasi, M. Mahjoob, and R. Yazdanpanah, Controlling of quadrotor uav using a fuzzy system for tuning the pid gains in hovering mode, 10th Int. Conf. Adv. Comput. Entertain. Technol, pp. 16, 2013. 